\title{
AVALIAÇÃO DE DESEMPENHO DE UM PROJETO PADRÃO DO PROGRAMA PROINFÂNCIA: ESCOLA DE EDUCAÇÃO INFANTIL NO SUL DO BRASIL
}

\author{
Post-occupancy evaluation of the standard project of \\ Proinfância program: early childhood education school in \\ south Brazil
}

\section{Nébora Lazzarotto Modler1, 2 , Angélica Saccol Berleze', Edison Kiyoshi Tsutsumi, 2 , Vinícius Cesar Cadena Linczuk, ${ }^{1}$, Giselle Arteiro Nielsen Azevedo'}

RESUMO: O Programa Nacional de Reestruturação e Aquisição de Equipamentos para a Rede Escolar Pública de Educação Infantil (Proinfância) investiu nos últimos anos na construção de novas escolas e na melhoria da infraestrutura com recursos federais do Plano de Aceleração do Crescimento. Contudo, a multiplicação de projetos padrão em nível nacional, sem a devida atenção às diversidades climáticas, pode gerar problemas, principalmente de desconforto térmico, em ambientes internos. Este trabalho apresenta uma Avaliação Pós-Ocupação (APO) de uma Escola Municipal de Educação Infantil (EMEI) localizada no sul do Brasil. O estudo teve por objetivo avaliar o desempenho de uma edificação oriunda de projeto padrão, bem como analisar a aplicação dos procedimentos e instrumentos usualmente empregados em APO, identificando suas vantagens e limitações. Em termos metodológicos foram aplicados os instrumentos Walkthrough, questionário e mapeamento visual. No que diz respeito à avaliação de desempenho, verificou-se a insatisfação com o piso da edificação, as circulações externas desprotegidas, o ruído advindo do pátio coberto, a inadequada localização do refeitório, as pequenas dimensões das salas de atividades e de repouso e a inexistência de banheiros próximos às salas. Quanto à aplicação dos instrumentos, verificou-se que o desenvolvimento do mapeamento visual permitiu ainda que aspectos que passaram despercebidos no questionário e no Walkthrough fossem identificados. Essa experiência confirma a importância da inserção de instrumentos de APO diversificados, a fim de que seja possível identificar e aprofundar fatores pertinentes às condições ambientais, bem como esclarecer apontamentos por meio do cruzamento de respostas. A pesquisa conclui a necessidade da revisão de alguns aspectos do projeto padrão do Proinfância no intuito de que haja um processo de qualificação constante e que possibilite as adaptações tanto ambientais quanto culturais, diante de um país tão diversificado.

PALAVRAS-CHAVE: Avaliação Pós-Ocupação; Desempenho; Proinfância; Escola de Educação Infantil.

ABSTRACT: The National Program for Restructuring and Equipment Acquisition for the Public Early Childhood School Network (Proinfância) has currently invested in the construction of new schools and in the improvement of the infrastructure with federal government resources of the Growth Acceleration Plan. However, the multiplication of standard projects throughout the country, without due attention to the climatic diversity, can generate problems, mainly of thermal discomfort, in internal environments. This work presents a Post-Occupancy Evaluation (POE) of an Early Childhood Education located in South of Brazil. The objective of the study was to evaluate the performance of a building from a standard project, as well as to analyze the application of the procedures and instruments usually employed in POE, identifying its advantages and limitations. In methodological terms the Walkthrough, Questionnaire and Visual Mapping instruments were applied. Concerning the

\section{How to cite this article:}

MODLER N.L.; BERLEZE A.S.; TSUTSUMI E.K.; LINCZUK V.C.C.; AZEVEDO G.A.N. Avaliação de desempenho de um projeto padrão do programa Proinfância: escola de educação infantil no sul do Brasil. Gestão e Tecnologia de Projetos, São Carlos, v. 13, n. 2, p. 95-118, 2018. http://dx.doi.org/10.11606/gtp.v13i2.126495
Fonte de financiamento: Conselho Nacional de Aperfeiçoamento de Pessoal de Nível Superior (CAPES) e o Programa Interinstitucional de Doutorado em Arquitetura (DINTER PROARQ-UFRJ/ UFFS)

Conflito de interesse: Declaram não haver

Submetido em: 09/02/2017 Aceito em: 17/04/2018 
performance evaluation, there was dissatisfaction with the floor of the building, with unprotected external circulations, noise coming from the covered patio, the inadequate location of the cafeteria, the small size of the classrooms and the lack of restrooms near the rooms. It was verified, with the application of the instruments, that the Visual Mapping also allowed that aspects that went unrecognized in the Questionnaire and the Walkthrough were identified. This experience confirms the importance of the inclusion of diversified POE instruments, so that it is possible to identify and deepen factors pertinent to environmental conditions, as well as to clarify notes through crossanswers. The research concludes the need to review some aspects of the standard project of Proinfância in order to have constant qualification process and that allow both environmental and cultural adaptations, in a such diverse country.

KEYWORDS: Post-Occupancy Evaluation; Performance; Proinfância; Early Childhood Education School.

\section{INTRODUÇÃO}

Este artigo é o desdobramento de uma Avaliação Pós-Ocupação (APO) realizada em julho de 2016, no âmbito de uma disciplina de doutorado ${ }^{1}$, em uma Escola Municipal de Educação Infantil (EMEI) vinculada ao Programa Nacional de Reestruturação e Aquisição de Equipamentos para a Rede Escolar Pública de Educação Infantil (Proinfância). A pesquisa avaliou as condições ambientais relativas ao conforto térmico, acústico e lumínico e, ainda, a funcionalidade dos principais ambientes internos da escola. Para além da avaliação de desempenho do ambiente construído, analisou-se a aplicação dos procedimentos e instrumentos usualmente empregados em APO, identificando suas vantagens e limitações.

O Proinfância foi criado em 2007 pelo Governo Federal com objetivo principal de prestar assistência aos municípios e Distrito Federal para construção e aquisição de equipamentos e mobiliário para creches e préescolas públicas (COELHO, 2015). Tal assistência é dada em caráter suplementar visto que é responsabilidade da União, bem como dos estados, exercer ação supletiva técnica e financeira, conforme afirmam os artigos 30 e 211 da Constituição Federal (BRASIL, 1988)².

Conforme Coelho (2015), a implementação do Proinfância abrange cinco dimensões: (1) disponibilização de projetos arquitetônicos-padrão; (2) financiamento de obras; (3) aquisição de mobiliário e equipamentos; (4) assessoramento técnico-pedagógico; (5) custeio de novas matrículas.

Ao Fundo Nacional para o Desenvolvimento da Educação (FNDE) foi atribuída a gestão nacional do Programa. O acompanhamento das etapas de execução das obras ocorre a partir do registro no Sistema Integrado de Monitoramento Execução e Controle do MEC - Simec (COELHO, 2015).

Segundo Flores e Albuquerque (2015, p. 22), o referido Programa "tem sido uma ação indispensável para a ampliação do acesso e da qualidade na oferta da Educação Infantil” no país, o que, se acredita, tende a minimizar as carências de instalações apontadas no documento preliminar de referência do MEC, Padrões de Infraestrutura para as Instituições de Educação Infantil, que menciona:

entendemos que ainda existe uma lacuna entre a reflexão teórica e a realidade concreta das edificações escolares, especialmente aquelas destinadas à educação infantil. Diversas unidades de educação infantil

1 Disciplina Avaliação de Desempenho do Ambiente Construído do Programa de Pós-Graduação em Arquitetura (PROARQ) da Universidade Federal do Rio de Janeiro (UFRJ), ministrado pela Prof. Dra. Giselle Arteiro Nielsen Azevedo.

2 Cf. a Constituição Federal (BRASIL, 1988): "Artigo 30: Compete aos Municípios: VI - manter, com cooperação técnica e financeira da União e do Estado, programas de educação infantil e de ensino fundamental”. "Artigo 211: A União, os Estados, o Distrito Federal e os Municípios organizarão em regime de colaboração seus sistemas de ensino - parágrafo $2^{\circ}$ : Os Municípios atuarão prioritariamente no ensino fundamental e na educação infantil”. 
funcionam em condições precárias de instalações de suprimento de serviços básicos, tais como: água, esgoto sanitário e energia elétrica. [...] O referido documento também considera que grande parte das edificações escolares existentes no país restrinja o processo educativo, já que muitas vezes sua concepção não facilita a exploração das possibilidades pedagógicas do espaço físico e de seus arranjos espaciais no desenvolvimento das diversas dimensões humanas de seus usuários (BRASIL, 2004, p. 3).

Essa consideração remete ao reconhecimento do potencial do espaçoambiente ${ }^{3}$ arquitetônico enquanto instrumento pedagógico, aspecto que é apontado por pesquisadores tanto do meio acadêmico da arquitetura como da pedagogia ${ }^{4}$. Segundo Faria (2003, p. 74), a organização do espaço físico das instituições de educação infantil é reconhecidamente importante para o desenvolvimento das dimensões humanas “o imaginário, o lúdico, o artístico, o afetivo, o cognitivo”, as quais são mencionadas no documento Critérios para atendimento em creches e pré-escolas que respeitem os direitos fundamentais da criança - COEDI/MEC ${ }^{5}$ (BRASIL, 1995).

Conforme o documento Parâmetros Básicos de Infraestrutura para as Instituições de Educação Infantil (BRASIL, 2006), bem como Kowaltowski (2011), a concepção do projeto escolar deve ser baseada em processos participativos que envolvam a comunidade educacional (crianças, professores, funcionários, pais, equipes diretivas), para que sejam incorporados os saberes, necessidades e desejos dos futuros usuários da edificação, bem como seja identificado o perfil pedagógico pretendido.

Contudo, os projetos escolares padronizados, entre os quais se inclui os do Proinfância, por basearem-se em modelos unificados para todo o país, acabam por desconsiderar sua diversidade, seja de ordem sociocultural, econômica ou climática, o que pode acarretar prejuízos quanto aos aspectos pedagógicos, de conforto ambiental, funcionais e técnico-construtivos.

Atualmente, o FNDE disponibiliza os projetos padrão Tipo 1 e Tipo 2, tendo sido descontinuados os projetos Tipo B e Tipo C. Os modelos apresentam poucas diferenciações em relação ao programa arquitetônico, também todos são planejados para serem implantados em lote cuja declividade máxima seja $3 \%$, contudo há diferenciação quanto às dimensões do lote, número de crianças atendidas, bem como em relação ao coeficiente de aproveitamento (CA) ${ }^{6}$.

O Tribunal de Contas da União realizou auditoria operacional em algumas escolas municipais de educação infantil (Emei) do Proinfância com projetos padrão Tipo B e Tipo C para identificar os riscos associados ao processo de expansão e funcionamento da rede pública de educação infantil (BRASIL, 2012). Os resultados apontam para a existência de fragilidades nos projetos, entre as quais estão inadequações em relação às variáveis climáticas que tornam os projetos padrão incapazes de se adequar às diferentes regiões do país. A partir dos apontamentos da auditoria, em 2013, o FNDE promoveu algumas alterações nos modelos Tipo B e C, entre elas a possibilidade de haver algumas adaptações no projeto para regiões de clima frio, tais como fechamento do pátio coberto/refeitório com vidro e piso em manta sintética.

A intenção de atuar na correção dos problemas já identificados é ainda presente. Segundo Peglow et al. (2016), os técnicos do FNDE manifestaram interesse em estruturar uma rede com grupos de pesquisa vinculados às

3 Ao adotar a palavra composta espaço-ambiente, nos alinhamos com Rheingantz et al. (2009) e Horn (2007). Segundo Rheingantz et al. (2009), o espaço se restringe apenas às qualidades físicas ou dimensionais, enquanto ambiente abrange os aspectos psicológicos e culturais atrelados à vivência das pessoas ocupantes do espaço.

4 Dentre os autores e pesquisadores pode-se mencionar CARVALHO \& RUBIANO, 1994; ZABALZA, 1998 ELALI, 2002; FARIA, 2003; CABANELLAS et al, 2005; HORN, 2004; MACHADO, 2008; SOUZA, 2009; FLORES \& ALBUQUERQUE, 2015.

5 Coordenação Geral de Educação Infantil do Ministério da Educação (COEDI), vinculada à Secretaria de Educação Básica do Ministério da Educação.

6 Tipo B: lote $40 \mathrm{~m} \times 70 \mathrm{~m}, 112$ vagas, CA de 0,35; Tipo C: lote $35 \mathrm{~m} \times 45 \mathrm{~m}, 60$ vagas, CA de 0,42; Tipo 1: lote $40 \mathrm{~m} \times 60 \mathrm{~m}, 188$ vagas, CA de 0,55 ; Tipo 2 : lote $35 \mathrm{~m} \times 45 \mathrm{~m}$, 94 vagas, CA de 0,49 ; Tipo 3 : lote $28 \mathrm{~m} \times 45 \mathrm{~m}, 188$ vagas, CA de 1,16 . 
universidades, com vistas a simular o desempenho termoenergético dos projetos padrão.

Nesse sentido, estudos de avaliação do ambiente construído com modelos do Proinfância em operação são relevantes a fim de, para além da análise térmica e de eficiência energética, verificar como os projetos atendem aos aspectos de bem-estar dos usuários infantis, no sentido de conforto ambiental, segurança, funcionalidade e potencial pedagógico. Para tanto, faz-se uso de instrumentos de avaliação já testados e validados para conseguir aproximar o olhar do pesquisador à percepção dos usuários.

\section{OBJETIVO}

Por meio do relato do estudo de caso $^{7}$ realizado em uma escola municipal de educação infantil (Emei) localizada no sul do Brasil, este artigo objetiva avaliar o desempenho do projeto-padrão do Programa Proinfância implantado no sul do Brasil, bem como analisar a aplicação de procedimentos e instrumentos usualmente empregados em APO, identificando suas vantagens e limitações.

\section{CONTEXTUALIZAÇÃO DO ESTUDO DE CASO}

A EMEI localiza-se na região Sul do Brasil, clima subtropical úmido, pertencente à Zona Bioclimática 2, conforme a NBR 15220 (ABNT, 2005, p. 3), apresentando predominância de desconforto por frio ao longo dos meses de maio a setembro.

Foi construída com o apoio do Ministério da Educação, por meio do Proinfância, com base no projeto-padrão FNDE Tipo B. Conforme o memorial descritivo desse projeto, as escolas de educação infantil desse padrão são térreas e possuem cinco blocos distintos de acordo com a função a que se destinam. São eles: bloco administrativo, bloco de serviços, bloco multiuso e dois blocos pedagógicos, todos interligados por circulação coberta. O conjunto também possui um pátio coberto, onde ocorrem as atividades de recreação e refeitório. $\mathrm{Na}$ área externa estão o playground, o castelo d'água e a área de estacionamento, além da torre de reservatório de água (BRASIL, 2013). O projeto arquitetônico prevê o atendimento a 112 crianças em turno integral, desde a série Berçário 1 até Pré-escola, conforme evidencia no Quadro 1 a seguir.

Figura 1: Planta baixa do projeto padrão FNDE Tipo B

Fonte: Adaptado de Fundo Nacional de Desenvolvimento da Educação (2013)

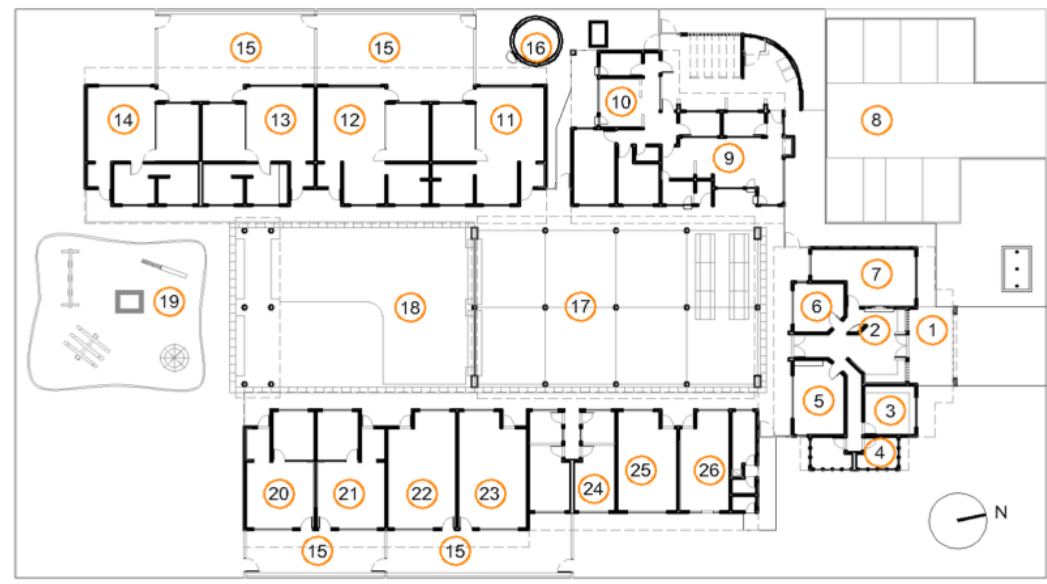

7 Os autores optam por manter o anonimato da instituição escolar. Salienta-se que este trabalho está aprovado na prefeitura municipal a qual a escola vincula-se sob o protocolo ${ }^{\circ}$ 2016/10211, bem como está aprovado na Plataforma Brasil e Comitê de Ética em Pesquisa, sob o CAAE 46952015.1.0000.5257, $\mathrm{n}^{\circ}$ de parecer 1.173 .490 
Quadro 1: Apresentação dos ambientes originais e adaptados na EMEl

\begin{tabular}{|c|c|c|c|c|c|}
\hline \multicolumn{2}{|r|}{$\begin{array}{l}\text { Ambiente } \\
\text { original }\end{array}$} & \multirow[t]{2}{*}{$\begin{array}{l}\text { Ambiente } \\
\text { adaptado }\end{array}$} & \multicolumn{2}{|r|}{$\begin{array}{c}\text { Ambiente } \\
\text { original }\end{array}$} & \multirow{2}{*}{$\begin{array}{c}\text { Ambiente } \\
\text { adaptado }\end{array}$} \\
\hline 1 & Hall de acesso & & 14 & $\begin{array}{c}\text { Creche } \| \\
\text { (1/2 anos) }\end{array}$ & \\
\hline 2 & Recepção & & 15 & Solário & \\
\hline 3 & Almoxarifado & Briquedoteca & 16 & Castelo d’água & \\
\hline 4 & $\begin{array}{l}\text { Sanitário de } \\
\text { funcionários }\end{array}$ & & 17 & $\begin{array}{l}\text { Pátio coberto e } \\
\text { refeitório }\end{array}$ & \\
\hline 5 & $\begin{array}{c}\text { Sala de } \\
\text { professores }\end{array}$ & & 18 & $\begin{array}{c}\text { Pátio externo } \\
\text { aberto }\end{array}$ & \\
\hline 6 & Diretoria & Jogoteca & 19 & Playground & \\
\hline 7 & Secretaria & $\begin{array}{c}\text { Secretaria e } \\
\text { direção }\end{array}$ & 20 & $\begin{array}{l}\text { Creche III } \\
\text { (2/4 anos) }\end{array}$ & $\begin{array}{l}\text { Maternal I } \\
\text { (2/3 anos) } \\
\end{array}$ \\
\hline 8 & Estacionamento & & 21 & $\begin{array}{l}\text { Creche III } \\
(2 / 4 \text { anos }) \\
\end{array}$ & $\begin{array}{l}\text { Maternal I } \\
(2 / 3 \text { anos }) \\
\end{array}$ \\
\hline 9 & Cozinha e apoio & & 22 & $\begin{array}{l}\text { Pré-escola } \\
(4 / 6 \text { anos }) \\
\end{array}$ & $\begin{array}{l}\text { Maternal II } \\
\text { (3/4 anos) } \\
\end{array}$ \\
\hline 10 & $\begin{array}{c}\text { Área de serviço e } \\
\text { lavanderia }\end{array}$ & & 23 & $\begin{array}{l}\text { Pré-escola } \\
(4 / 6 \text { anos }) \\
\end{array}$ & $\begin{array}{l}\text { Maternal II } \\
\text { (3/4 anos) }\end{array}$ \\
\hline 11 & $\begin{array}{c}\text { Creche I } \\
\text { (0/1 ano) }\end{array}$ & $\begin{array}{l}\text { Berçário I } \\
\text { (0/1 ano) }\end{array}$ & 24 & Sanitário infantil & \\
\hline 12 & $\begin{array}{l}\text { Creche I } \\
\text { (0/1 ano) }\end{array}$ & $\begin{array}{l}\text { Berçário II } \\
\text { (0/1 ano) }\end{array}$ & 25 & $\begin{array}{l}\text { Leitura/sala } \\
\text { multiuso }\end{array}$ & $\begin{array}{c}\text { Sala de } \\
\text { atendimento } \\
\text { educacional } \\
\text { especial }\end{array}$ \\
\hline 13 & $\begin{array}{l}\text { Creche } \| \\
(1 / 2 \text { anos })\end{array}$ & $\begin{array}{l}\text { Berçário II } \\
\text { (0/1 ano) }\end{array}$ & 26 & Informática & $\begin{array}{c}\text { Informática/ } \\
\text { biblioteca/vídeo }\end{array}$ \\
\hline
\end{tabular}

Fonte: adaptado de Fundo Nacional de Desenvolvimento da Educação (2013)

No caso da EMEI estudada, no ano de 2016, o número de salas e as séries ofertadas foram: uma turma de Berçário I ( 0 a 1 ano), três turmas de Berçário II (1 a 2 anos), duas turmas de Maternal I ( 2 a 3 anos) e duas turmas de Maternal II (3 a 4 anos). Em relação à estrutura administrativa, a escola possuía: diretora, vice-diretora e coordenadora pedagógica, professoras regentes, atendentes auxiliares, funcionárias da cozinha/limpeza e vigia noturno.

No memorial descritivo original do projeto padrão consta a possibilidade de adaptações de elementos construtivos atendendo as particularidades regionais observadas e as necessidades de conforto espacial e térmico atendidas em regiões de clima frio, são elas: fechamento do pátio coberto com esquadrias com abertura de correr, utilização de forro nas salas de aula a fim de reduzir o pé-direito interno para 2,70m e alteração de revestimento do piso das salas de atividades com manta sintética.

Na EMEI estudada, realizou-se efetivamente o fechamento do pátio coberto com esquadrias e a instalação de cobertura na circulação externa, entre os blocos de serviço e pedagógico, para facilitar o fluxo de funcionários em dias de chuva, bem como inserido forro de madeira na cobertura do pátio coberto. Do projeto original, contudo, foram mantidos o piso em granitina e o pé-direito de 3,00m com a cobertura em laje, não havendo forro.

$\mathrm{Na}$ intenção de ampliar os espaços de uso das crianças, a direção da Emei optou por adaptar o uso de alguns ambientes. Assim, onde o projetopadrão original previu o almoxarifado, ocorre a brinquedoteca (Figura 2), já a sala de direção foi adaptada para atender a jogoteca (Figura 3), sendo 
Figura 2: Espaço

adaptado para receber a brinquedoteca

Fonte: Os autores (2016)

Figura 3: Espaço adaptado para receber a jogoteca

Fonte: Os autores (2016) que as atividades de direção e almoxarifado desenvolvem-se junto do atual espaço da secretaria.
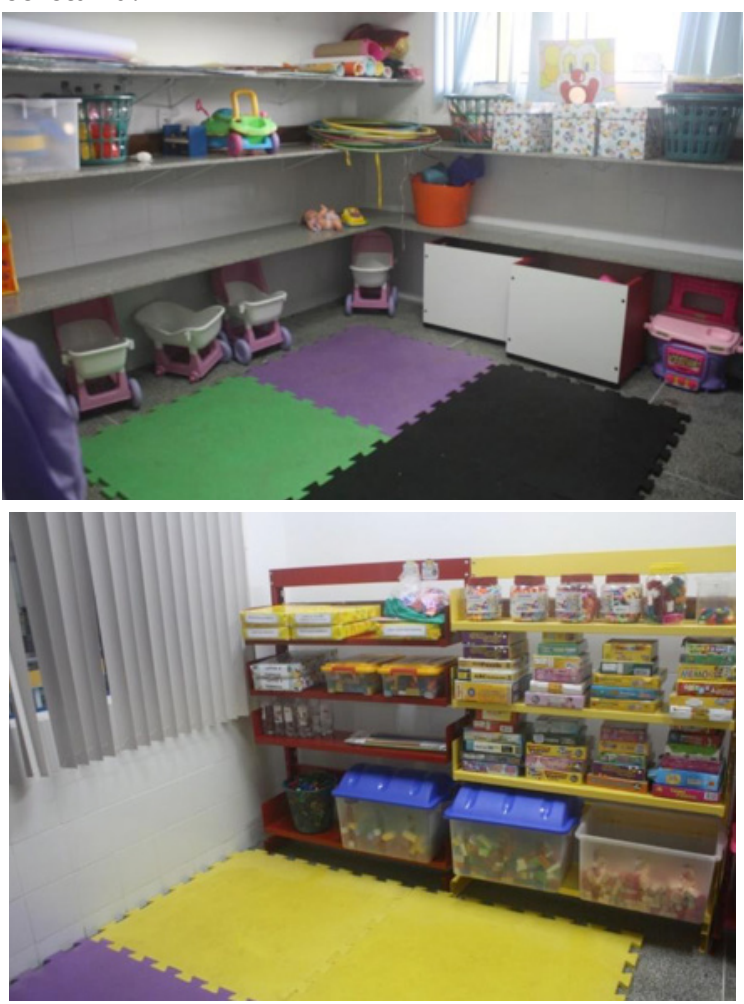

\section{MÉTODOS}

\section{Embasamento conceitual dos métodos}

Em alinhamento com os grupos de pesquisa ProLUGAR e GAE (ProArq/FAU/UFRJ), para a realização deste trabalho seguiu-se a postura investigativa da Abordagem Experiencial ${ }^{8}$ e seu desdobramento prático, a Observação Incorporada, que, segundo Rheingantz et al. (2009, p. 107), "propõe a transformação da postura ou atitude do observador, de abstrata e desincorporada, para uma atitude de observação aberta e atenta do ambiente, considerando pessoa-ambiente de forma indissociável e interdependente”.

Walkthrough é um instrumento de $\mathrm{APO}^{9}$ que consiste na realização de um percurso feito pelos pesquisadores para a compreensão do estado e uso dos ambientes a partir da observação conjugada com entrevistas e técnicas de registros (fotográfico, desenho e gravação). Nesse sentido, são identificadas características positivas e negativas dos aspectos construtivos e a relação com a apropriação dos ambientes pelos usuários. Além disso, é um instrumento que geralmente precede os demais por orientar a realização de estudos mais aprofundados e quais técnicas e instrumentos devem ser os próximos utilizados (RHEINGANTZ et al., 2009). Segundo Zeisel (1981), a primeira Análise Walkthrough foi feita por Lynch em 1960.

8 Designação utilizada pelos pesquisadores dos grupos GAE e ProLUGAR/ProArq/UFRJ para caracterizar as avaliaç̃̃es do desempenho do ambiente construído alinhadas com a valorização da experiência vivenciadas pelo observador.

9 Um dos objetivos da APO é a avaliação do desempenho da edificação em relação a fatores técnicos, funcionais, econômicos, estéticos e comportamentais do ambiente em uso. Segundo Orsntein (1992), a APO tem origem, como campo de investigação, em pesquisas realizadas pela Midwest Psychological Field Station, da cidade de Oskaloosa, associada à University of Kansas, Estados Unidos. O Instituto foi fundado por Roger Barker e Herbert Wright em 1947 e pretendia investigar as influências da sociedade no desenvolvimento da criança. 
O questionário compreende o instrumento que possui uma série de perguntas a serem respondidas sem a presença do pesquisador e que podem ser enviadas pessoalmente, por internet ou correio. É o instrumento ideal quando se pretende descobrir regularidades entre grupos de pessoas por meio da comparação entre as respostas. Indica-se ainda que as questões sejam simples, precisas e neutras, de modo a não influenciar os respondentes (ZEISEL, 1981).

Mapeamento visual é um instrumento que permite ao pesquisador identificar a percepção dos usuários em relação a um determinado ambiente, a apropriação dos espaços, sua satisfação em relação ao lugar e em relação ao mobiliário, entre outros. Segundo Rheingantz et al. (2009), o mapeamento visual foi desenvolvido por Ross Thorne em 1991. A ferramenta possibilita que o usuário registre em plantas os pontos positivos e negativos do ambiente analisado, possibilitando o entendimento em relação ao bem-estar de seus usuários. Ainda segundo os autores, essa técnica dispensa a formalização verbal, possibilitando uma maior liberdade e interação entre o usuário e o pesquisador, contribuindo para uma melhor eficácia de outras técnicas a serem aplicadas posteriormente. Conforme os autores, o mapeamento visual pode ter diversas abordagens, desde a mais abrangente até as mais pragmáticas e focalizadas, como é o caso de análises referentes ao conforto ambiental. Independentemente do tipo de abordagem, o resultado da aplicação de um mapeamento visual deve ser cruzado com os resultados de métodos complementares.

\section{A escolha dos instrumentos e a sua ordem de aplicação}

O grupo de pesquisadores foi formado por quatro professores universitários, todos arquitetos e urbanistas, sendo dois homens e duas mulheres ${ }^{10}$.

A avaliação de desempenho desenvolveu-se em dois dias. No primeiro dia, em manhã chuvosa de inverno, com temperatura em torno de $15^{\circ} \mathrm{C}$, foi feita uma visita preliminar exploratória pelos ambientes da escola com o acompanhamento da diretora e coordenadora pedagógica, as quais conduziram os pesquisadores e explicaram toda a dinâmica de funcionamento da escola. Após esse primeiro contato, foram definidos os instrumentos APO que seriam aplicados, bem como preparados os materiais gráficos e textuais necessários à sua aplicação.

A escolha dos instrumentos foi pautada no tempo restrito disponível para a realização da APO e no enfoque de conforto ambiental elencado para a análise de desempenho. Ficou também definido que o grupo focal da pesquisa seria composto pelas professoras e gestoras da escola, visto que, no entendimento dos pesquisadores, uma interação com as crianças necessitaria mais tempo para que elas se acostumassem com a presença dos pesquisadores. Para além disso, em função de o enfoque da avaliação ser conforto ambiental, os pesquisadores julgaram que as professoras e gestoras conseguiriam, no tempo disponível, comunicar com mais êxito os aspectos inerentes às questões envolvidas.

Assim, por meio da Análise Walkthrough, seria possível obter a observação técnica dos pesquisadores, a qual estava embasada na conversa (não estruturada) com a professora no interior do ambiente avaliado. E, por meio do mapeamento visual e questionário, seria possível obter a percepção isolada das professoras sobre os ambientes da edificação, a qual seria cruzada novamente com os resultados da Walkthrough.

No segundo dia de visita, ocorrida em dia nublado, com temperatura do ar em torno de $15^{\circ} \mathrm{C}$, desenvolveu-se a aplicação efetiva dos instrumentos presenciais ora mencionados. Primeiramente, com início às 8 h30min, desenvolveu-se a Análise Walkthrough, a qual teve a duração de três horas, aproximadamente. No turno da tarde, os pesquisadores dialogaram inicialmente a respeito das principais percepções oriundas da Walkthrough, e, em seguida, ajustaram algumas perguntas já previamente definidas para serem realizadas no mapeamento visual. A aplicação do mapeamento visual ocorreu na sala de professores, onde, uma a uma, as professoras foram recebidas pelos pesquisadores.

10 Nébora Lazzarotto Modler, Angélica Saccol Berleze, Edison Kiyoshi Tsutsumi, Vinicius Cesar Cadena Linczuk 
Os formulários referentes aos questionários foram deixados sob os cuidados da secretária da escola para que as professoras e gestoras, ainda no mesmo dia, os retirassem e os levassem para casa, a fim de que contribuíssem com o processo de avaliação fora de seus horários de trabalho.

\section{DISCUSSÃO DOS RESULTADOS}

A apresentação dos resultados segue a ordem da aplicação dos instrumentos.

\section{Observações da Análise Walkthrough}

Como já mencionada, a Análise Walkthrough precedeu e norteou a aplicação dos demais instrumentos. Ela foi orientada por um checklist e por plantas da edificação que foram sendo preenchidas e retificadas na medida em que se considerou necessário. O checklist desenvolvido foi preenchido observando os seguintes critérios: nome do ambiente, área, pé-direito, ocupantes, atividades, mobiliário, materiais de revestimento, iluminação, ventilação e equipamentos. Já as plantas foram utilizadas para registrar layouts e confirmar as dimensões das esquadrias, com o auxílio de uma trena manual e fotografias do local.

O percurso iniciou-se pelo acesso principal da escola em direção à sala de atividades do Berçário I. Em seguida a equipe passou por uma sala do Berçário II, Maternal I, Maternal II, sala de atendimento educacional especial (SAEE), uma sala compartilhada de biblioteca e informática e, ao final, o pátio coberto. A escolha desses ambientes deu-se principalmente na tentativa de contemplar salas destinadas a diferentes faixas etárias, posição solar e relação com o pátio central coberto. A Figura 4 traz o percurso no qual os ambientes foram sinalizados por letras.

Constatou-se que a escola apresenta os mesmos materiais de acabamento em todas as salas, com paredes de alvenaria, revestimento de cerâmica branca até 1,20m, reboco liso e pintura acrílica branca acima, cobertura em laje pré-moldada e telha cerâmica. O piso demonstrou ser frio sendo perceptível o desconforto por assimetria térmica causado durante o período da visita.

Figura 4: Percurso da Análise Walkthrough

Fonte: Adaptado de Fundo Nacional de Desenvolvimento da Educação (2016)

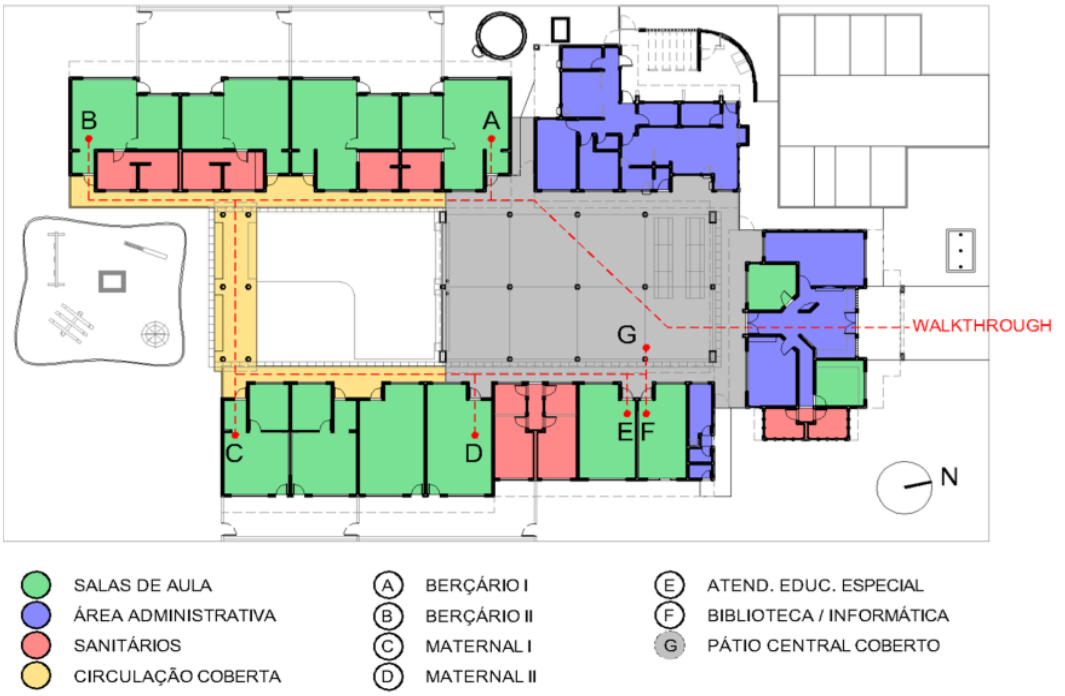

Berçário /

Dados gerais:

Professoras: 2

Crianças: 0 a 1 ano 
Área: $57,35 \mathrm{~m}^{2}$

Ambientes: atividades, alimentação, repouso e fraldário

Mobiliário: bancada com pia, armários, tapete emborrachado, 9 carrinhos de bebê, televisão, micro-ondas, condicionador de ar e 5 luminárias de teto, 10 berços, ventilador e 2 arandelas

OBS: Correspondente ao ambiente $n^{0} 11$ na Figura 1 e Quadro 1
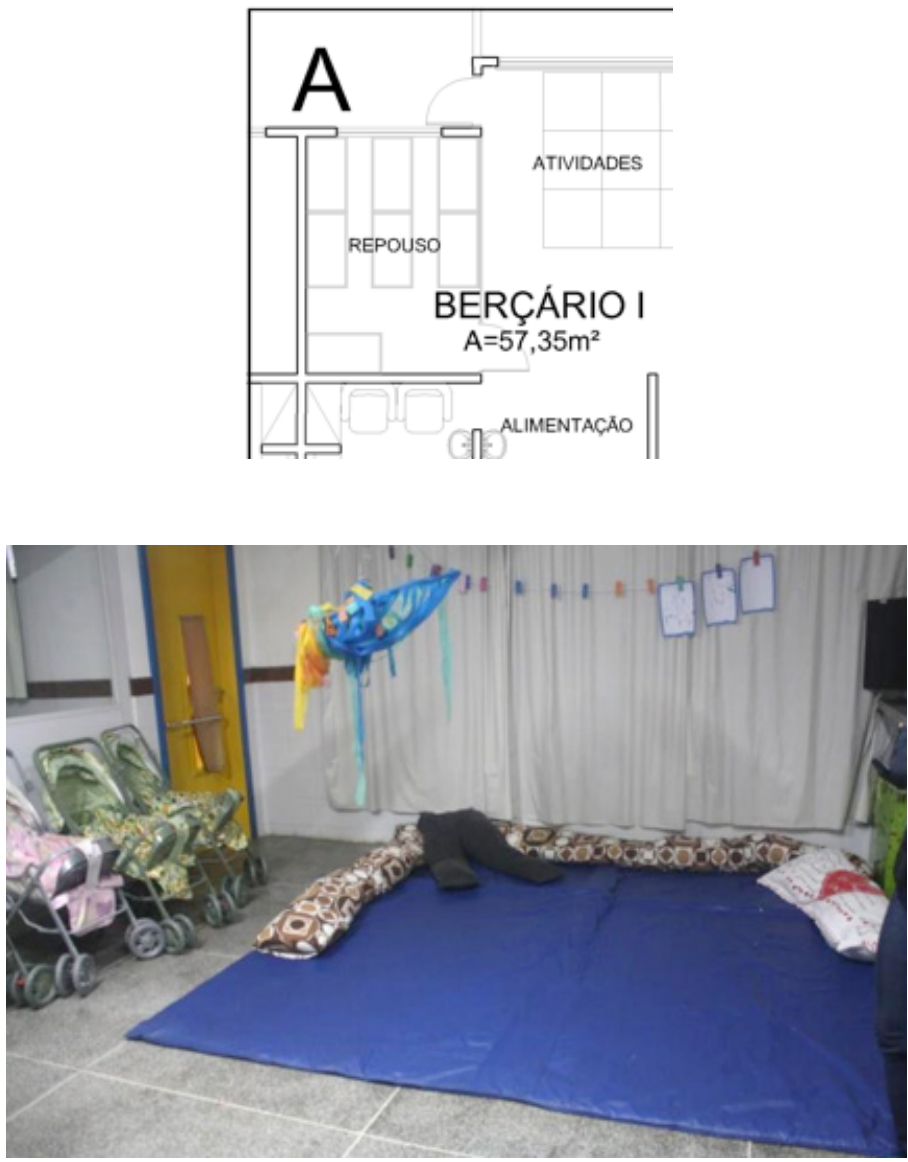

A sala de atividades do Berçário I tem acesso pelo pátio coberto/refeitório e possui comunicação direta com o solário orientado para oeste (Figuras 5 e 6).

Embora os ambientes de atividades e repouso possuam amplas janelas com orientação oeste, notou-se a existência de pouca iluminação natural. Isso se deve em razão da obstrução parcial causada pelo castelo d'água e o uso de cortina blackout. Além disso, há janelas com dimensões reduzidas voltadas para o pátio central e que são encobertas por papel kraft na tentativa de escurecer o ambiente e reduzir o ruído para o momento de sono das crianças. Nesse sentido, a ventilação que poderia ser cruzada também é prejudicada em razão da impossibilidade de abertura dessas janelas, o que pode ser a razão do ambiente apresentar, no dia da visita, sensação de umidade. Em relação à ventilação e climatização mecânica, a professora destacou a necessidade maior de uso do condicionador de ar da sala de atividades no período frio e, ainda, a não utilização do ventilador de teto da sala de descanso em função do ruído que ele gera.

\section{Berçário //}

Dados gerais:

Professoras: 2

Crianças: 1 a 2 anos

Área: $57,35 \mathrm{~m}^{2}$

Ambientes: atividades, repouso e sanitário
Figura 5: Planta baixa Berçário |

Fonte: Adaptado de Fundo Nacional de Desenvolvimento da Educação (2013)

Figura 6: Foto do Berçário I

Fonte: Os autores (2016) 
Figura 7: Planta baixa do Berçário II

Fonte: Adaptado de Fundo Nacional de Desenvolvimento da Educação (2013)

Figura 8: Foto dos solários dos Berçários | e ||

Fonte: Os autores (2016)
Mobiliário: bancada com pia, armários, tapete emborrachado, 3 mesas com cadeiras, condicionador de ar e 4 luminárias de teto, 5 berços, 5 camas desmontáveis, ventilador e 2 arandelas

OBS: Correspondente ao ambiente $n^{\circ} 14$ na Figura 1 e Quadro 1

O ambiente do Berçário II tem acesso protegido apenas por beiral, sem fechamento lateral, e possui comunicação direta com o solário orientado para oeste (Figura 7).
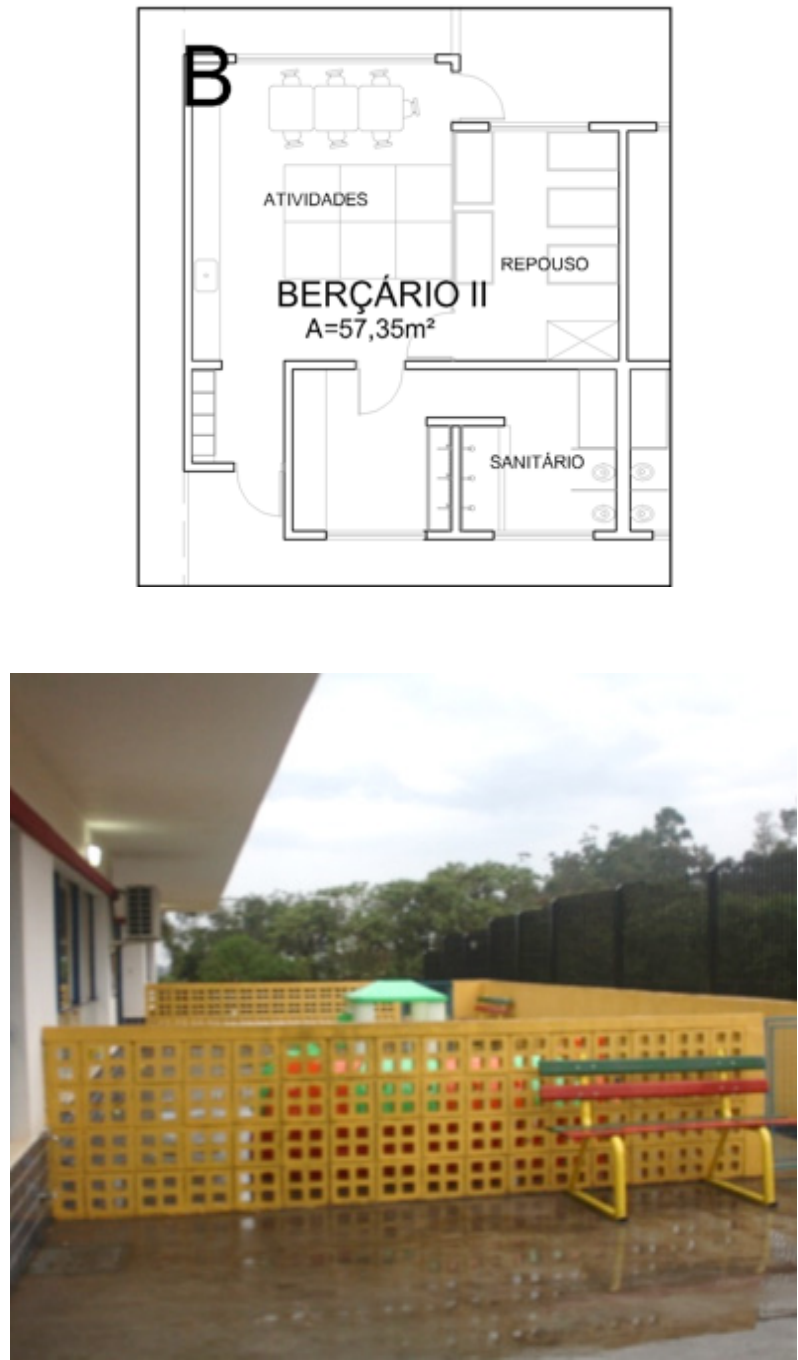

À semelhança da sala de atividades destinada ao Berçário I, os ambientes de atividades possuem amplas janelas com orientação oeste e janelas com dimensões reduzidas, em posição oposta, orientadas para o pátio coberto. As janelas são mantidas fechadas, prejudicando a possibilidade de ventilação cruzada e causando a sensação de umidade, principalmente no ambiente dos sanitários. A abertura das janelas também é prejudicada pelo modelo ser pivotante vertical e feita de ferro, as quais são pesadas e de difícil manuseio. A sala dá acesso ao solário, que conta com piso em concreto bruto cujo acabamento áspero pode ocasionar acidentes às crianças (Figura 8). O sanitário é dividido em um ambiente de lavatório e outro para banho, troca e vasos sanitários.

Maternal I

Dados gerais:

Figura 9: Planta baixa do Maternal I 
Fonte: Adaptado de Fundo Nacional de Desenvolvimento da Educação (2013)

Professoras: 4

Crianças: 2 a 3 anos

Área: $36,20 \mathrm{~m}^{2}$

Ambientes: atividades e repouso

Mobiliário: bancada com pia, armários, 2 mesas desmontáveis, 16 cadeiras, 4 luminárias de teto e 24 camas desmontáveis

OBS: Correspondente ao ambiente $\mathrm{n}^{\circ} 20$ na Figura 1 e Quadro 1
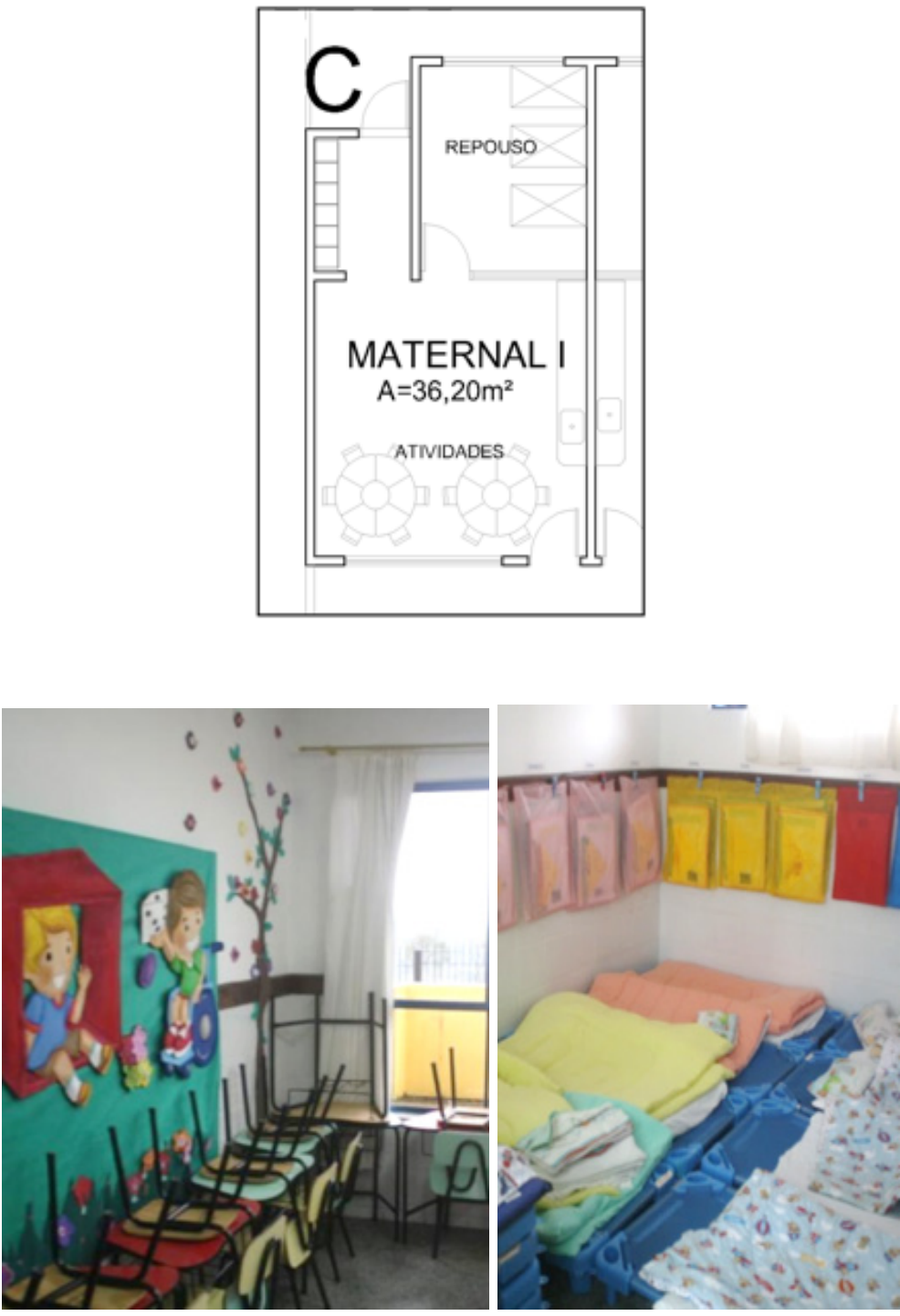

O ambiente do Maternal I tem acesso protegido apenas por beiral, sem fechamento lateral, e possui comunicação direta com o solário orientado para leste (Figuras 9, 10 e 11). Não há banheiro na sala, estando localizado no pátio central compartilhado.

O ambiente possui amplas janelas com orientação leste e janelas pequenas, em posição oposta, orientadas para o pátio externo aberto. Nota-se uma melhor condição de iluminação natural e ventilação cruzada proporcionada pela divisória baixa desobstruída. A sala também possui acesso ao solário com acabamento de piso em concreto bruto.
Figura 9: Planta baixa do Maternal I

Fonte: Adaptado de Fundo Nacional de Desenvolvimento da Educação (2013)

Figura 10: Foto do Maternal I

Fonte: Os autores (2016)

Figura 11: Foto do Repouso

Fonte: Os autores (2016) 


\section{Maternal /l}

Dados gerais:

\section{Professoras: 4}

Crianças: 3 a 4 anos

Área: $36,20 \mathrm{~m}^{2}$

Ambientes: atividades e repouso

Mobiliário: bancada com pia, armários, tapete emborrachado, quadro branco, 26 mesas com cadeiras, 4 luminárias de teto, 28 camas desmontáveis

OBS: Correspondente ao ambiente $n^{\circ} 23$ na Figura 1 e Quadro 1

Figura 12: Planta baixa do Maternal II

Fonte: Adaptado de Fundo Nacional de Desenvolvimento da Educação (2013)

Figura 13: Foto da sala do Maternal II

Fonte: Os autores (2016)
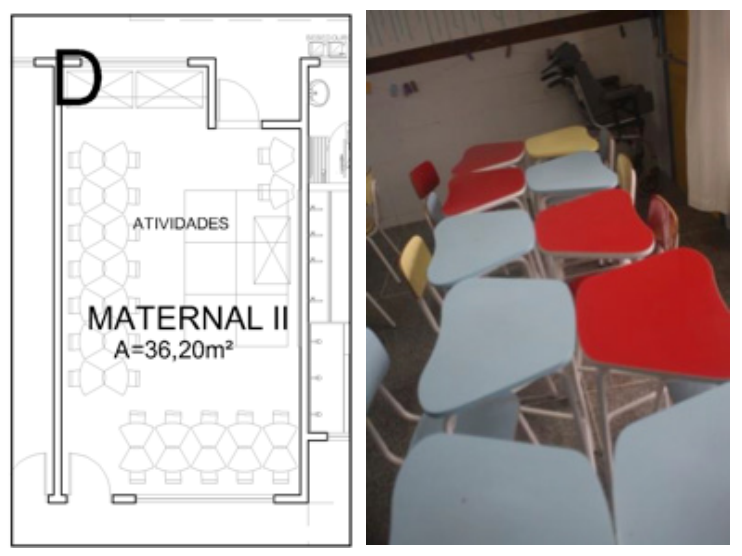

O ambiente tem acesso através do pátio coberto/refeitório e possui comunicação direta com o solário orientado para leste (Figura 12).

A sala possui ampla janela com orientação leste e janelas com dimensões reduzidas, em posição oposta, orientadas para o pátio coberto/refeitório. A ventilação cruzada é facilitada em razão de não haver divisórias na sala, contudo, as janelas orientadas para o pátio permanecem fechadas grande parte do tempo devido ao ruído oriundo desse espaço.

As professoras relataram preferirem mesas coletivas para propiciar trabalho em grupo, tendo em vista que as atuais mesas, além de possuírem altura inadequada à faixa etária dos usuários, quando agrupadas, geram vazios que possibilitam a queda dos materiais didáticos, o que acaba por desconcentrar as crianças do foco das atividades (Figura 13). Em razão da profundidade da sala, há necessidade do uso da iluminação artificial.

\section{Sala de Atendimento Educacional Especial (SAEE)}

A Sala de Atendimento Educacional Especial (SAEE) possui ocupação variável, sendo utilizada para atividades individuais com crianças especiais e para outras atividades diversas. Essa sala apresentou-se adequada à atividade proposta (Figura 15).

Dados gerais:

\section{Professoras: 1}

Crianças: variável

Área: $27,10 \mathrm{~m}^{2}$

Ambientes: atividades individuais com crianças especiais e atividades motoras com turmas dos maternais

Mobiliário: prateleiras, 1 mesa, 4 cadeiras, tapete emborrachado, equipamentos para as atividades motoras, 3 luminárias de teto (não possui condicionador de ar ou ventilador)

OBS: Correspondente ao ambiente n 25 na Figura 1 e Quadro 1 

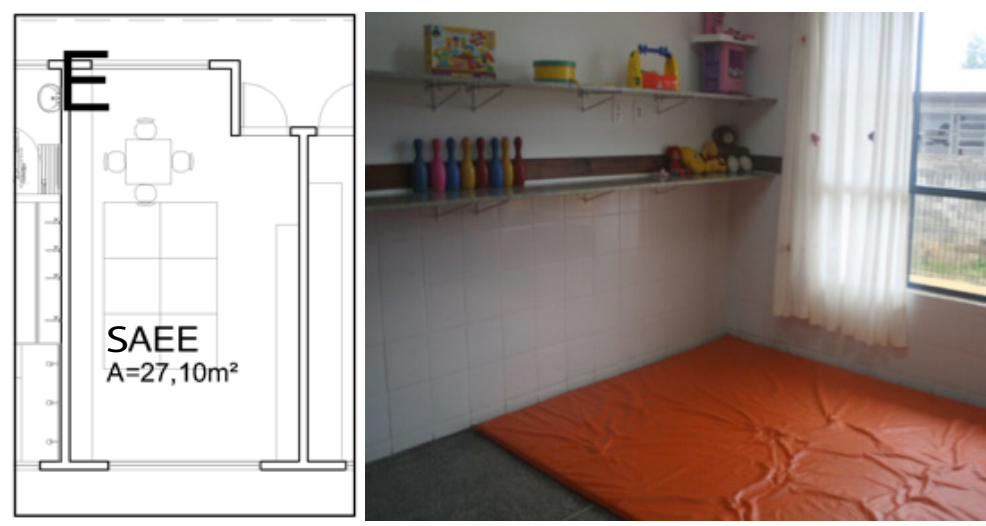

Biblioteca/informática

A sala da biblioteca e informática recebe as crianças para atividades específicas de dinâmica de jogos e uso de computador e vídeo. As cadeiras apresentam-se altas para a faixa etária atendida pela escola, e a altura das prateleiras, em $65 \mathrm{~cm}$, oferecem risco de acidentes. (Figura 17 e 18).

Dados gerais:

Professoras: 1

Crianças: variável

Área da biblioteca/informática: $22,88 \mathrm{~m}^{2}$

Ambientes: contação de histórias e atividades com computadores

Mobiliário: prateleiras, 7 computadores, 12 cadeiras, televisão, 4 luminárias de teto e condicionador de ar

OBS: Correspondente ao ambiente $\mathrm{n}^{\circ} 26$ na Figura 1 e Quadro 1
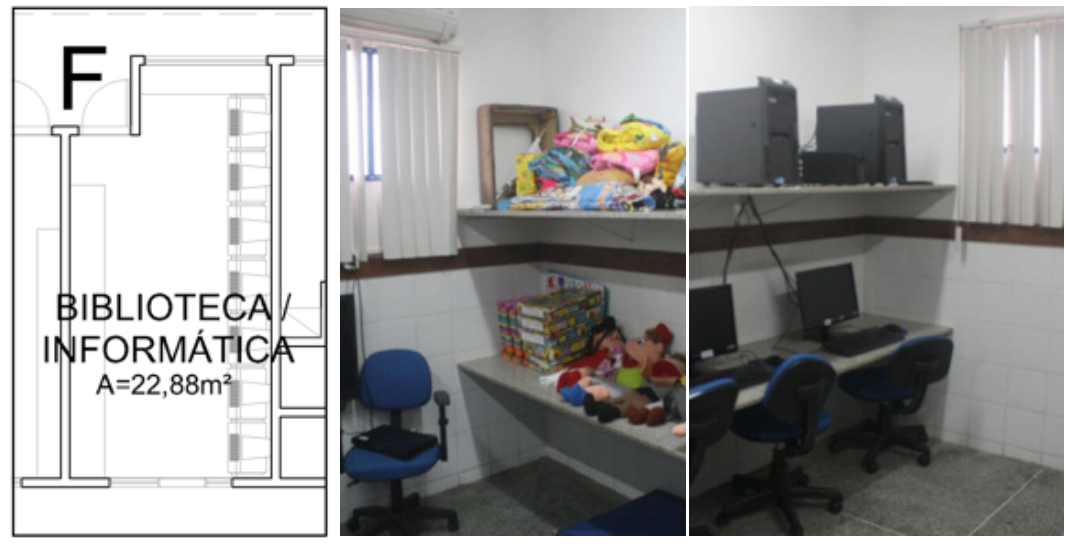

\section{Sanitários}

Os sanitários são utilizados pelas crianças das turmas dos maternais. 0 acesso aos sanitários ocorre pelo pátio coberto/refeitório. Suas aberturas são orientadas para a fachada leste, sendo estas com dimensões reduzidas, o que ocasiona iluminação natural precária. Além disso, as esquadrias são em ferro e de difícil manuseio. As paredes são revestidas por cerâmica até a altura de 1,85m, e o piso é em granitina. Observou-se que a distância da borda do lavatório até a torneira não é adequada para o alcance manual das crianças da faixa etária de 3 a 4 anos, bem como o revestimento em cerâmica lisa dos degraus da escada de acesso ao chuveiro expõe as crianças ao risco de queda (Figuras 19 e 20).
Figura 14 Planta baixa da SAEE

Fonte: Adaptado de Fundo Nacional de Desenvolvimento da Educação (2013)

Figura 15: Foto da SAEE

Fonte: Os autores (2016)

Figura 16: Planta baixa da biblioteca e informática

Fonte: Adaptado de Fundo Nacional de Desenvolvimento da Educação (2013)

Figura 17: Biblioteca

Fonte: Os autores (2016)

Figura 18: Informática

Fonte: Os autores (2016) 
Figura 19: Fotos dos lavatórios

Fonte: Os autores (2016)

Figura 20: Fotos do espaço de banho

Fonte: Os autores (2016)

Figura 21: Pátio coberto/ refeitório

Fonte: Os autores (2016)

Figura 22: Pátio coberto/ refeitório

Fonte: Os autores (2016)
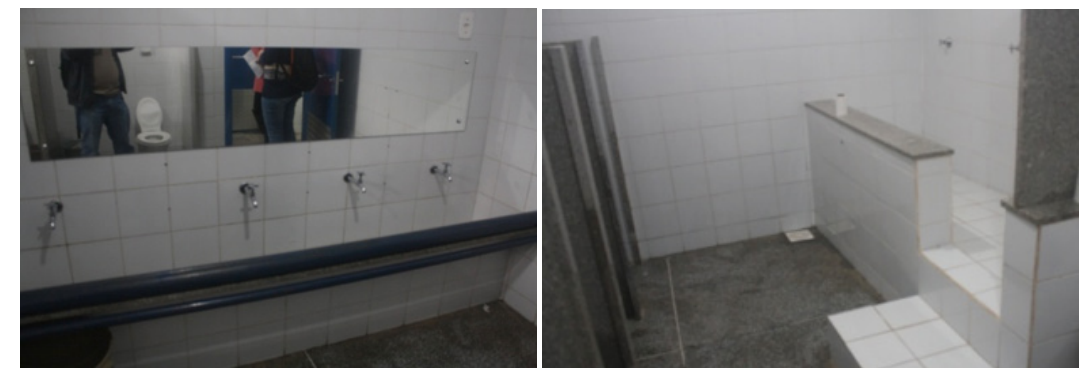

Pátio coberto

O pátio coberto apresenta uma área de $220,0 \mathrm{~m}^{2}$. Possui piso em granitina, e a cobertura apresenta-se em estrutura de madeira, telha cerâmica e forro de madeira. Como adaptação ao clima frio, o pátio conta com fechamentos verticais em vidro temperado fixo, bem como portas e janelas de correr, também em vidro temperado. $\mathrm{O}$ ambiente atende a função de circulação e de refeitório, tendo as mesas localizadas em frente à cozinha, e área de brinquedos com casinha de bonecas, escorregador, cama elástica, entre outros. Tal agrupamento de funções evidencia problema de incompatibilidade, uma vez que as crianças não se concentram em suas refeições devido à visualização atrativa dos brinquedos. Também o fato de as mesas de refeição estarem expostas a um ambiente amplo, sujeito a maior circulação de poeira, demanda limpeza constante das mesas (Figuras 21 e 22).

Além disso, o piso em granitina e os fechamentos em vidro são reflexivos às ondas sonoras, o que torna o ambiente ruidoso. Para evitar a perturbação do ruído advindo do pátio, as professoras das salas do Berçário I e Maternal II relataram que mantêm as janelas orientadas para o pátio sempre fechadas, o que impossibilita a ventilação natural cruzada desses ambientes.
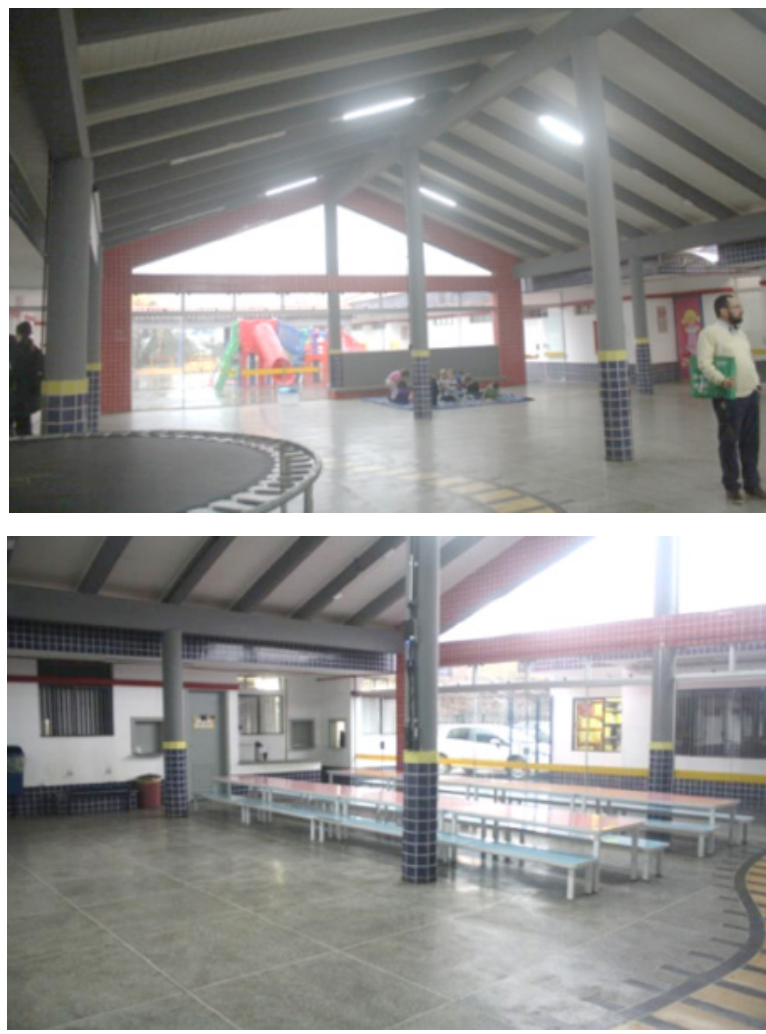


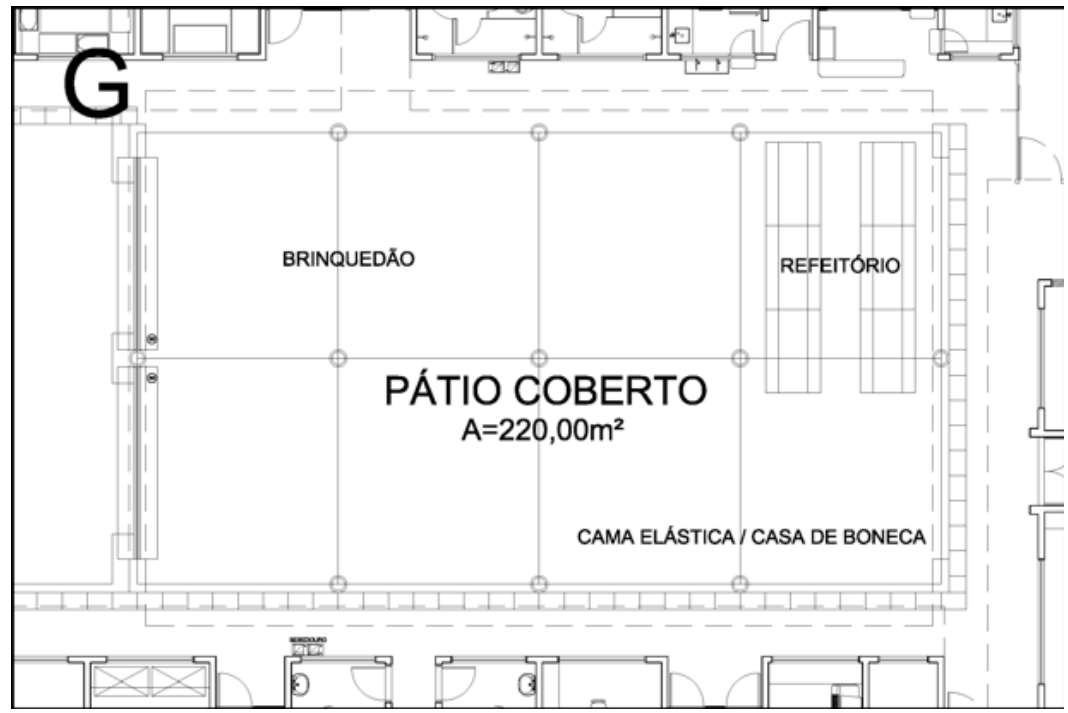

Circulações externas

Em relação às áreas de circulação, constatou-se que elas expõem os usuários ao desconforto por frio. O hall de acesso da escola, o qual apresenta aberturas com cobogós, causa corrente de ar indesejável no inverno, pois está alinhado com a circulação que leva ao pátio coberto/refeitório (Figuras 24 e 25). Também o acesso às salas, por ser aberto, com proteção apenas de beiral, expõe as crianças ao frio e à umidade no período do inverno (Figura 26).
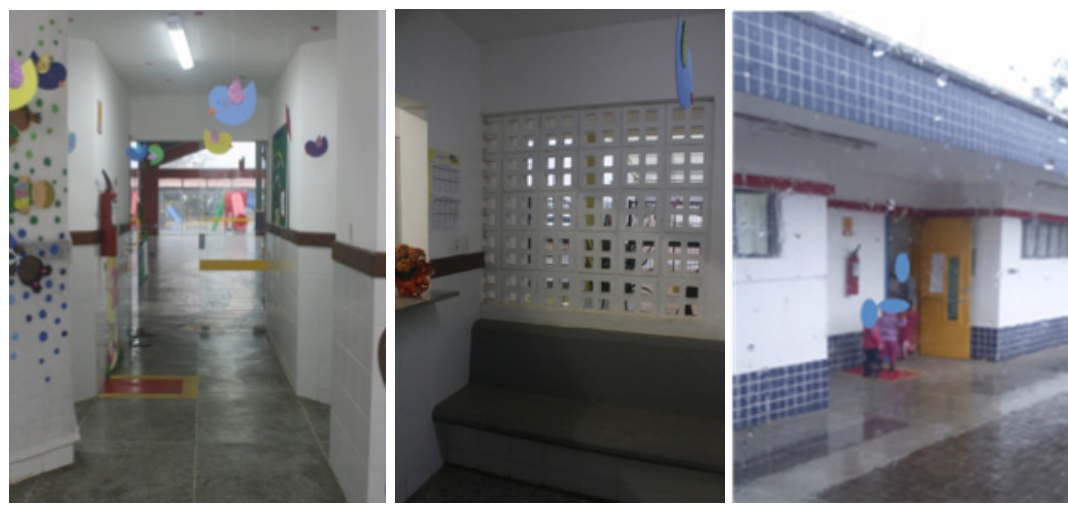

\section{Mapeamento visual}

Em função de a APO ter restrições de tempo para sua aplicação, optouse por realizar o mapeamento visual com apenas 4 professoras regentes de turmas. A definição de quais profissionais seriam convidadas a participar partiu da localização das salas de atividades em que atuam, ou seja, com qual turma trabalham. Assim, optou-se por convidar as professoras do Berçário I e Berçário II, cujas salas são orientadas para o oeste, e as professoras do Maternal I e Maternal II, cujas salas são voltadas para leste, a fim de se obter suas percepções sobre o conforto ambiental.

Quanto à sistemática de aplicação, o mapeamento visual assemelhouse a uma entrevista. Uma a uma, as professoras foram recebidas pelos pesquisadores na sala dos professores e convidadas a comentar sobre os principais ambientes da escola com base na visualização da planta baixa da escola.
Figura 23: Planta do pátio coberto/refeitório

Fonte: Adaptado de Fundo Nacional de Desenvolvimento da Educação (2013)

Figura 24: Circulação principal de entrada

Fonte: Os autores (2016)

Figura 25: Cobogós no hall de entrada

Fonte: Os autores (2016)

Figura 26: Acesso à sala do Maternal I

Fonte: Os autores (2016) 
Os ambientes avaliados foram: salas de atividades em que a professora trabalha, SAEE, biblioteca/informática, pátio coberto/refeitório, playground, sanitários e circulações entre os blocos. Para cada ambiente a respondente deveria considerar as questões de ruído, calor, frio, odor, dimensionamento do espaço, tranquilidade, convivência e agradabilidade, definindo se considerava o ambiente "positivo" ou "negativo" em cada um dos aspectos elencados. Ao julgar o ambiente como positivo, a professora era convidada a colocar um ponto de caneta azul sobre a sua localização em planta e, caso o julgasse como negativo, deveria inserir um ponto de caneta vermelha.

No entanto, logo no início da aplicação do instrumento, durante a primeira entrevista, devido aos comentários da professora, os pesquisadores perceberam a necessidade de incluir outras questões que também se mostravam importantes. Assim, foram incluídos os aspectos: segurança, visibilidade (ou ponto cego de visualização da sala), ventilação e layout.

Todos os quatro pesquisadores estavam presentes ao longo da aplicação do mapeamento visual. Uma pesquisadora ficou responsável pela transcrição da entrevista, outra desenvolveu a interlocução com a professora e os demais acompanhavam a atividade em silêncio. Não foi utilizado gravação de áudio.

De forma geral, as respostas reincidentes apontam:

a) área insuficiente das salas para a realização das atividades e problemas de layout, ou seja, espaços pouco funcionais e pouco flexíveis para uso pedagógico;

b) com relação ao ruído interno, as professoras do Berçário I e Maternal II apontam que há ruído oriundo do pátio coberto, levando-as a manter as janelas voltadas para esse ambiente fechadas, o que prejudica as taxas de renovação de ar em suas salas;

c) as professoras do Maternal I e II comentam que há odor desagradável de caixas de passagem da rede de esgoto localizadas no pátio externo aberto, aspecto que só foi descoberto com a aplicação desta avaliação, o que evidencia a necessidade de uso de instrumentos diversificados em APO;

d) o solário foi lembrado como um ambiente em que se utiliza apenas em um turno, ou seja, conforme a condição favorável de insolação; o piso em concreto bruto foi apontado como inadequado devido ao risco de as crianças se machucarem;

e) destacaram a área de ventilação insuficiente nos ambientes de repouso;

f) o pátio coberto/refeitório é apontado por problemas de layout, visto que consideram o uso compartilhado entre refeitório e recreação como problemático. Também, todas as respondentes afirmam que o pátio coberto é um ambiente frio no inverno e desconfortável acusticamente devido ao ruído gerado no próprio ambiente;

g) todas as professoras consideram as áreas da brinquedoteca e jogoteca insuficientes, visto que os locais foram adaptados para se tornarem esses ambientes, sendo originalmente projetados para ser o almoxarifado e a diretoria, respectivamente;

h) a sala de vídeo/biblioteca também é considerada subdimensionada e desconfortável em função do calor e da ventilação insuficiente. Já a SAEE foi considerada um ambiente predominantemente agradável e bem ventilado.

De forma geral, as respondentes demonstraram facilidade de leitura gráfica da planta baixa e orientação espacial, o que viabilizou a aplicação do instrumento, bem como a confiabilidade das respostas. Também, a experiência vivenciada evidenciou a importância de se realizar um testepiloto do instrumento antes da sua aplicação efetiva a fim de que seja possível identificar antecipadamente quais são as questões ambientais mais pertinentes.

\section{Observações sobre o questionário}

O questionário foi o último instrumento a ser aplicado no estudo de caso. As questões e formulários foram elaborados pelos pesquisadores após a 
realização da visita exploratória, ou seja, na tarde do primeiro dia de estudo de campo. Considera-se que o percurso vivenciado na visita foi imprescindível para a definição de quais seriam os questionamentos importantes a serem abordados no questionário.

O questionário foi disponibilizado em meio físico a toda equipe diretiva, coordenação pedagógica, professoras regentes de turma e estagiárias auxiliares de turma, o que totalizou 28 pessoas. No que tange às professoras ${ }^{11}$, do total de 23 que atuam na escola, 17 trabalham na instituição entre dois e três anos, o que é positivo para a análise dos resultados, pois já vivenciaram situações sazonais diversas para embasar respostas mais esclarecidas, como verões e invernos mais ou menos rigorosos.

Os formulários foram disponibilizados na secretaria da escola para que cada respondente retirasse o seu e o levasse para casa, a fim de que o envolvimento com a atividade ocorresse fora do horário de trabalho. Foi acordado um prazo de 3 dias para que as respondentes retornassem os formulários para a secretaria, local onde seriam recolhidos pelos pesquisadores. Ao final, obtevese o retorno de 23 respondentes, o que corresponde a $82 \%$ do grupo total.

O questionário foi elaborado com questões de opinião, com escala verbal, de respostas pares, variando entre "muito bom", "bom", "ruim” e "muito ruim", totalizando 38 perguntas. Além disso, foram elaboradas questões dicotômicas, variando entre "sim" e "não", totalizando 33 perguntas. Ao final das séries de perguntas referentes a um determinado ambiente, foram deixados espaços em branco possibilitando comentários gerais.

Primeiramente, a respondente deveria marcar em uma planta baixa esquemática a sala de atividades em que permanece a maior parte do dia a fim de verificar se há divergência de conforto entre as salas das faces leste e oeste. As perguntas visaram avaliar os mesmos ambientes enfocados no mapeamento visual a fim de confrontar os resultados dos diferentes instrumentos. Foram assim alvo de questões os seguintes ambientes: salas de atividades das turmas, pátio coberto/refeitório, banheiros, circulações e pátio externo.

Em relação às perguntas que se referem às salas de atividades, sobressaem as seguintes respostas:

a) respectivamente, $70 \%$ e $87 \%$ das respondentes consideram as dimensões das salas de atividades e de repouso inadequadas;

b) a maioria (87\%) afirma estar exposta ao frio no inverno, o que coincide com a resposta de grande parte das professoras (91\%), que consideram 0 piso inadequado. Fazendo uma interpretação integrada às observações do Walkthrough, é possível inferir que grande parte do desconforto por frio é proveniente do contato com o piso de granitina, que segue o projeto padrão Proinfância/FNDE;

c) com relação à escada dos sanitários revestida de cerâmica lisa (Figura 17), a maioria (74\%) aponta que ela é inadequada porque oferece risco por ser escorregadiça, contudo apontam que a sua altura está adequada para a atividade de dar banho na criança;

d) no que tange à funcionalidade do mobiliário e à quantidade de iluminação natural, a maioria considerou adequada;

e) as considerações em relação ao desconforto por frio no inverno e os problemas dimensionais e de flexibilidade das salas de atividades foram apontados negativamente;

f) algumas professoras apontaram problema do ruído, justamente as que trabalham em salas mais próximas ao pátio coberto/refeitório;

g) o tamanho das aberturas e a quantidade de iluminação natural e artificial foram mencionadas positivamente.

Em relação às perguntas sobre as áreas de circulação (hall de acesso e áreas de entrada das salas), as respostas revelam que esses ambientes são desconfortáveis por frio, inclusive o hall de acesso da escola, o qual apresenta aberturas com cobogós que causam correntes de ar indesejáveis no inverno.

$11100 \%$ das professoras respondentes são do sexo feminino e possuem ensino superior completo, sendo que 15 delas também possuem pós-graduação concluída. 
Além disso, a localização dos sanitários foi declarada como desfavorável por ser distante das salas. Nesse sentido, é necessário considerar que, com exceção do Berçário I e Maternal II, todas as outras salas têm acesso protegido apenas pela projeção do beiral, não havendo fechamento lateral. Com relação às respostas referentes ao pátio externo, sobressaem as informações sobre as dimensões desse espaço serem adequadas para atividades das crianças, o que foi apontado por $91 \%$ das respondentes. Contudo, segundo $70 \%$ das professoras, há carência de árvores para sombreamento no verão.

Ao longo da análise dos resultados também se constatou a importância desse instrumento oferecer um campo para considerações livres por parte dos respondentes, visto que contribuições relevantes foram obtidas a partir dessa alternativa de resposta no questionário, as quais foram colaborações primordiais para a análise integrada das informações em relação aos outros instrumentos utilizados.

\section{Síntese das descobertas}

A análise dos resultados da APO apontam que o projeto padrão da edificação contém fragilidades principalmente em relação às seguintes questões:

a) ambientes subdimensionados para atender aspectos funcionais, as salas de atividades e de repouso não contam com área suficiente para as atividades pedagógicas e de descanso das crianças;

b) o pátio coberto é associado, principalmente, aos problemas de geração de ruído e de incompatibilidades funcionais. O ruído da recreação das crianças nos brinquedos se propaga por meio dos materiais de acabamento reflexivos e perturba as salas de atividades adjacentes, as quais contam com aberturas voltadas para o pátio coberto. A área de refeitório, também presente nesse espaço, além de exposta ao ruído, é prejudicada pela poeira resultante da circulação dos usuários, bem como a concentração das crianças no momento da refeição é dispersada pela visualização atrativa dos brinquedos;

c) com relação ao desconforto por frio, considera-se que sua causa é, em grande parte, devido ao piso em granitina presente em todos os ambientes da escola. O projeto original também não atende a diversidade climática do sul do Brasil ao prever circulações abertas que dão acesso às salas de atividades, com exceção das salas do Berçário I e Maternal II, conforme evidencia a Figura 1. Em dias frios e chuvosos, crianças e professoras necessitam circular expostas ao vento e à umidade, situação essa que se torna mais crítica para as turmas dos maternais que não contam com sanitários junto das salas de atividades;

d) a questão da ventilação insuficiente foi identificada, principalmente, devido ao subdimensionamento das esquadrias dos sanitários, do fraldário e da área de repouso e alimentação dos berçários. Além do que, no caso do Berçário I, identificou-se que as esquadrias são, grande parte do tempo, mantidas fechadas em função do ruído advindo do pátio coberto.

O Quadro 2 apresenta a síntese das descobertas verificadas ao longo da aplicação dos instrumentos, bem como algumas recomendações para a melhoria dos espaços. É importante destacar que algumas descobertas só poderiam ser retificadas com obras de ampliação da escola e, nesse sentido, não foram feitas proposições a nível de projeto. As recomendações aqui listadas servem como contribuição da pesquisa, e a longo prazo deve auxiliar na retroalimentação de projetos futuros para escolas de educação infantil no sul do Brasil. 


\begin{tabular}{|c|c|c|c|}
\hline & Ferramenta & Descobertas & Recomendações \\
\hline & Questionário & $\begin{array}{l}\text { O ambiente de repouso apresenta-se subdimensionado. } \\
\text { A sala possui ventilador que não é utilizado em função do ruído. } \\
\text { A sala de atividades possui condicionador de ar que é mais utilizado no inverno, pois é a estação que mais causa desconforto } \\
\text { térmico. } \\
\text { A sala de atividades possui uma ampla janela voltada para oeste que é sombreada pelo castelo d’agua (reservatório de } \\
\text { água), prejudicando a iluminação natural. } \\
\text { O ambiente de refeições possui uma janela pequena mas que possibilitaria a ventilação cruzada. No entanto ela é mantida } \\
\text { fechada. } \\
\text { A ausência de porta separando a sala de atividades do fraldário faz com que haja odores na sala. } \\
\text { A dimensão das salas é insuficiente, principalmente o ambiente de repouso. } \\
\text { A renovação de ar no inverno é insuficiente. } \\
\text { Há ruído proveniente do pátio coberto. } \\
\text { Há necessidade de uma sala isolada para amamentação. } \\
\text { A área da sala de repouso é subdimensionada. }\end{array}$ & $\begin{array}{l}\text { Há necessidade de ampliação dos } \\
\text { ambientes de repouso. } \\
\text { Prever instalação de piso emborrachado } \\
\text { em todos os ambientes internos a fim } \\
\text { reduzir desconforto por frio. } \\
\text { Prever substituição das esquadrias de } \\
\text { ferro por alumínio de modo a facilitar o } \\
\text { manuseio e aumentar a estanqueidade do } \\
\text { ambiente, bem como instalar vidros com } \\
\text { controle térmico. } \\
\text { Prever porta dividindo a sala de atividades } \\
\text { do fraldário em função do odor. } \\
\text { No solário é necessário instalar piso }\end{array}$ \\
\hline & $\begin{array}{c}\text { Mapeamento } \\
\text { Visual }\end{array}$ & $\begin{array}{l}\text { O layout da sala de atividades dificulta a interação das crianças com a paisagem externa, que muitas vezes sobem no } \\
\text { mobiliário para observar através da janela. } \\
\text { A sala possui ambiente contíguo para sanitários e chuveiros e lavatórios. O tamanho das janelas é muito pequeno e de difícil } \\
\text { abertura em função do material, o que dificulta a renovação do ar. O acesso ao chuveiro é feito por uma escada com piso liso } \\
\text { e escorregadio. } \\
\text { O solário, o qual é orientado para oeste, é pouco usado no turno da tarde no verão, devido à insolação excessiva. } \\
\text { O piso de concreto bruto é considerado inadequado devido ao risco de escoriações nas crianças em caso de queda. } \\
\text { A dimensão das salas é insuficiente, principalmente o ambiente de repouso. } \\
\text { A escolha do piso em granitina é inadequada em função do frio. } \\
\text { Há desconforto por frio. } \\
\text { A renovação de ar no inverno é insuficiente. } \\
\text { A insolação que atinge a sala no turno da tarde torna o ambiente demasiadamente aquecido no verão, o que ocasiona o uso } \\
\text { do climatizador de ar. } \\
\text { O espaço da sala de repouso é subdimensionado e mal-ventilado. } \\
\text { O banheiro da sala é mal dimensionado e apresenta ventilação insuficiente. } \\
\text { O hall de acesso à sala consiste em um ponto cego visto da sala de atividades. } \\
\text { O piso do solário, com acabamento áspero, compromete a segurança das crianças. }\end{array}$ & $\begin{array}{l}\text { Tamborrachado resistente às intempéries. } \\
\text { sombreamento, preferencialmente com } \\
\text { vegetação do tipo caducifólia. } \\
\text { O Berçário I não deveria ter comunicação } \\
\text { direta com o pátio coberto, visto que } \\
\text { os bebês não utilizam esse espaço de } \\
\text { - recreação, que gera ruído. } \\
\text { Instalar piso antiderrapante nas áreas de } \\
\text { banho dos sanitários, evitando que as } \\
\text { crianças escorreguem. } \\
\text {. Rever o tipo de mobiliários do Maternal } \\
\text { II para que seja mais ergonômico para a } \\
\text { faixa etária das crianças que utilizam o } \\
\text { ambiente. }\end{array}$ \\
\hline
\end{tabular}


Quadro 2: Continuação

\begin{tabular}{|c|c|c|c|}
\hline \multirow{3}{*}{ 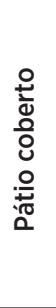 } & Walkthrough & $\begin{array}{l}\text { O espaço é utilizado para brincadeiras, refeições e circulação, prejudicando a concentração das crianças no momento da } \\
\text { refeição, além de gerar acúmulo de poeira nas mesas com facilidade. } \\
\text { Em função das atividades desenvolvidas e dos materiais de revestimento serem reflexivos às ondas sonoras, o ambiente } \\
\text { apresenta ruído, prejudicando as atividades nas salas próximas. }\end{array}$ & \multirow{10}{*}{$\begin{array}{l}\text { Prever instalação de divisória em gesso } \\
\text { com isolamento acústico para separar } \\
\text { fisicamente os ambientes e proteger } \\
\text { acusticamente o refeitório do pátio } \\
\text { coberto. } \\
\text { Instalar materiais acusticamente } \\
\text { absorventes no piso e nas paredes do pátio } \\
\text { coberto. } \\
\text { Isolar a tubulação de esgoto. } \\
\text { Prever a instalação de piso emborrachado } \\
\text { em todo o pátio. } \\
\text { Plantar árvores de modo que protejam } \\
\text { os brinquedos da insolação excessiva } \\
\text { no verão, sugere-se optar por espécies } \\
\text { caducas. } \\
\text { Instalar brinquedos adequados à faixa } \\
\text { etária das crianças. }\end{array}$} \\
\hline & Questionário & $\begin{array}{l}\text { O tipo de piso é inadequado. } \\
\text { A presença do refeitório no ambiente do pátio é inadequada. }\end{array}$ & \\
\hline & $\begin{array}{l}\text { Mapeamento } \\
\text { Visual }\end{array}$ & $\begin{array}{l}\text { Pátio coberto é muito quente no verão e muito frio no inverno. } \\
\text { O parquinho gera muito ruído para as crianças que estão fazendo as refeições. }\end{array}$ & \\
\hline \multirow{3}{*}{ 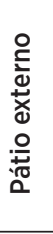 } & Walkthrough & $\begin{array}{l}\text { Piso de concreto bruto dificulta as atividades desenvolvidas no espaço. } \\
\text { Falta sombreamento no verão, e a utilização gera ruídos para as salas. }\end{array}$ & \\
\hline & Questionário & $\begin{array}{l}\text { Há insolação excessiva no verão, causando desconforto em função da radiação solar direta durante essa estação, e no } \\
\text { inverno, em função do vento frio. }\end{array}$ & \\
\hline & $\begin{array}{l}\text { Mapeamento } \\
\text { Visual }\end{array}$ & Há carência de espaços sombreados para atender ao período de verão. & \\
\hline \multirow{4}{*}{ 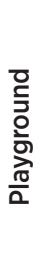 } & Walkthrough & $\begin{array}{l}\text { Alguns brinquedos do parquinho são inadequados à faixa etária das crianças. } \\
\text { Não há árvores para proporcionar sombreamento no verão. } \\
\text { O piso de grama e areia é pouco drenante, dificultando a utilização após longos períodos de chuva. }\end{array}$ & \\
\hline & Questionário & $\begin{array}{l}\text { Professoras e gestoras consideram que o tamanho dos brinquedos do playground é inadequado para a faixa etária dos } \\
\text { alunos. }\end{array}$ & \\
\hline & Mapeamento & Não há sombra na caixa de areia e nos brinquedos para atender ao período de verão. & \\
\hline & & & \\
\hline
\end{tabular}




\section{CONSIDERAÇÕES FINAIS}

Neste trabalho foi apresentado um estudo de caso com aplicação de instrumentos de APO em uma EMEI localizada na região Sul do Brasil. A avaliação teve como enfoque as condições relativas a conforto ambiental, segurança, funcionalidade e potencial pedagógico dos principais ambientes internos da escola. A aplicação dos instrumentos ocorreu em dois dias chuvosos de inverno, com temperaturas em torno de $15^{\circ} \mathrm{C}$, durante parte prática da disciplina Avaliação de Desempenho do Ambiente Construído (PROARQ/UFRJ).

Em termos metodológicos, realizou-se uma pesquisa experimental com aplicação de instrumentos qualitativos. A pesquisa teve caráter observatório, e os instrumentos avaliaram a percepção das professoras e gestoras com base nas suas experiências de vivência do espaço escolar, bem como a percepção dos pesquisadores conforme alinhamento com a Abordagem Experiencial e Observação Incorporada.

As principais limitações do estudo de campo foram oriundas do curto espaço de tempo entre a aplicação dos instrumentos, o que ocasionou uma reflexão limitada dos pesquisadores na proposição de um instrumento com base nos seus resultados. Verificou-se, por exemplo, a importância de o questionário ser elaborado após a aplicação do Walkthrough e mapeamento visual, assim como após os resultados terem sido analisados, visto que dessa forma os pesquisadores teriam a possibilidade de explorar melhor a potencialidade das perguntas. Também se confirmou a importância da aplicação de pré-testes antes da realização definitiva do mapeamento visual, de modo que aspectos relevantes não deixem de ser investigados.

A pesquisa deteve-se na área construída, sem abordar as áreas de recreação abertas da escola, as quais são compostas pelo pátio aberto, o qual é pavimentado, o playground e as áreas de taludes com grama localizadas no recuo lateral leste do lote. Esses espaços não fizeram parte da análise Walkthrough e foram exploradas com poucas perguntas no questionário, contudo foram levantados comentários das professoras durante o mapeamento visual, os quais apontaram pontos positivos e negativos, bem como o grande apreço das crianças em relação às vivências de brincadeiras nesses espaços.

Considera-se que, para além da contribuição técnica com a retroalimentação de projetos padrão de escolas de educação infantil, a experiência desta APO fortalece a importância de que o projeto do ambiente escolar infantil deve partir de diretrizes transdisciplinares da pedagogia e da arquitetura a fim de que o espaço-ambiente não tenha só função de proporcionar condições adequadas de habitabilidade, mas sim possa contribuir no processo educativo. Dessa forma será possível, cada vez mais, superar os conceitos de creches assistencialistas, comuns no Brasil há pouco mais de uma década, as quais eram instaladas em edificações adaptadas para esse uso.

A utilização de instrumentos de APO diversificados é imprescindível para identificar o "olhar" do professor e do pesquisador, que representam, respectivamente, o olhar fruto da vivência diária e da pedagogia e o olhar técnico do arquiteto. A experiência desta pesquisa demonstra a importância do cruzamento dessas percepções para que a avaliação alcance a compreensão da diversidade de usos e significados que o ambiente escolar infantil possui e que o projeto deveria atender.

As principais contribuições dos professores são de caráter pedagógico, funcional e de segurança, questões que podem tornar-se "invisíveis" aos olhos dos pesquisadores. Como exemplo, tem-se o piso do solário em concreto com acabamento áspero, identificado pelas educadoras como inadequado devido ao risco de as crianças se machucarem em possíveis quedas, e por não ser confortável nem estimulante para as crianças se apropriarem - como sentar, engatinhar e andar de joelhos.

Já a observação dos pesquisadores, no caso arquitetos, é capaz de identificar aspectos que passam despercebidos aos professores por estes já estarem acostumados com espaço da escola, como, por exemplo, a insuficiência de ventilação das salas de berçário e fraldário, ocasionado pela área reduzida 
de esquadrias prescrita pelo projeto-padrão e pela dificuldade de manuseio dos caixilhos em ferro. Ao encontro dessas constatações, os comentários das professoras apontam a necessidade de manter fechadas as esquadrias voltadas para o pátio coberto em função do ruído advindo desse espaço, o que prejudica a qualidade do ar interno, pois dessa forma não ocorre a ventilação cruzada e higiênica.

Por fim, acredita-se que o estudo contribui com a comunicação de uma experiência de observação sobre como o projeto padrão Proinfância/FNDE é vivenciado por seus usuários infantis e educadoras. Nesse sentido, conclui-se que há necessidade de o modelo atual de projetos do Programa Proinfância serem revistos no intuito de que haja um processo de qualificação constante a fim de atender as diversidades do país.

\section{REFERÊNCIAS}

ASSOCIAÇÃO BRASILEIRA DE NORMAS TÉCNICAS. NBR 15220-3: desempenho térmico de edificações - Parte 3: zoneamento bioclimático brasileiro e diretrizes construtivas para habitações unifamiliares de interesse social. Rio de Janeiro, 2005.

BRASIL. Constituição da República Federativa do Brasil de 1988. Brasília, DF, 5 out. 1988. Disponível em: <https://goo.gl/2ejvKu>. Acesso em: 21 dez. 2015.

. Ministério da Educação. Secretaria de Educação Infantil e Fundamental. Padrões de Infraestrutura para as Instituições de Educação Infantil e Parâmetros de Qualidade para a Educação Infantil. Brasília, DF, 2004. Disponível em: <https://goo.gl/ePyQgf>. Acesso em: 21 dez. 2015. Documento preliminar.

Ministério da Educação. Secretaria de Educação Básica. Critérios para uma atendimento em creches que respeite os direitos fundamentais das crianças. Brasília, DF, MEC/SEB/COEDI, 1995.

Ministério da Educação. Parâmetros Básicos de Infraestrutura para as Instituições de Educação Infantil. Brasília, DF, 2006. 2 v. Disponível em: <https://goo.gl/6xubfL>. Acesso em: 7 ago. 2016.

. Ministério da Educação. Fundo Nacional de Desenvolvimento da Educação. Memorial descritivo: projeto Proinfância: tipo B. Brasília, DF, 2013. Disponível em: <https:// goo.gl/ZbkKuQ>. Acesso em: 7 ago. 2016.

Ministério da Educação. Programa Nacional de Reestruturação e Aparelhagem da Rede Escolar Pública de Educação Infantil (Proinfância). Brasília, DF, 2016. Disponível em: <https://goo.gl/S1fGzQ>. Acesso em: 8 maio 2018.

Tribunal de Contas da União. TC 011.441/2012-7: relatório de auditoria. Brasília, DF, 2012. Disponível em: <https://goo.gl/ gaZWFW>. Acesso em: 14 mar. 2018.

CABANELLAS, I.; E., Clara (Orgs.); FORNASA, W.; HOYUELOS, A.; POLONIO, R.; TEJADA,
M. Territorios de la infância. Diálogos entre arquitectura y pedagogía. Barcelona: Editorial Graó, 2005. 250 páginas.CARVALHO, M. I. C.; RUBIANO, M. R. B. Organização do espaço em instituições pré-escolares. In: OLIVEIRA, Z. M. R. Educação infantil: muitos olhares. São Paulo: Cortez, 1994. p. 116-142.

COELHO. R. C. F. Prefácio. In: FLORES, M. L. R.; ALBUQUERQUE, S. S.(Orgs.). Implementação do PROINFÂNCIA no Rio Grande do Sul: perspectivas políticas e pedagógicas. Porto Alegre: EDIPUCRS, 2015. p. 7-8. Livro Eletrônico disponível emhttp://ebooks.pucrs. br/edipucrs/Ebooks/Pdf/978-85-397-0663-1. pdf, consulta 13 ago. 2016.

ELALI, G. A. Ambientes para educação infantil: um quebra-cabeça? Contribuição metodológica na Avaliação Pós-Ocupação de edificações e na elaboração de diretrizes para projetos arquitetônicos na área. 2002. 320 f. Tese (Doutorado em Estruturas Ambientais Urbanas) - Faculdade de Arquitetura e Urbanismo, Universidade de São Paulo, São Paulo, 2002.

FARIA, A. L. G. O espaço físico como um dos elementos fundamentais para uma pedagogia infantil. In: FARIA, A. L. G.; PALHARES, M. (Orgs.). Educação infantil pós-LDB: rumos e desafios. 4. ed. Campinas: Autores Associados, 2003. p. 67-100.

FLORES, M. L. R.; ALBUQUERQUE, S. S.(Orgs.), Implementação do PROINFÂNCIA no Rio Grande do Sul: perspectivas políticas e pedagógicas. PortoAlegre: EDIPUCRS, 2015. Livro Eletrônico disponível emhttp://ebooks. pucrs.br/edipucrs/Ebooks/Pdf/978-85-3970663-1.pdf, consulta13agosto2016.

FUNDO NACIONAL DE DESENVOLVIMENTO DA EDUCAÇÃO. Memorial descritivo: Projeto Proinfância: Tipo B. Brasília, DF, 2013. Disponível em: <https://goo.gl/7ShWLc>. Acesso em: 7 ago. 2016.

HORN, M. G. S. Sabores, cores, sons, aromas a organização dos espaços na educação infantil. Porto Alegre: Artmed, 2004. 
KOWALTOWSKI, D. C. C. K. Arquitetura e escolar o projeto do ambiente de ensino. São Paulo: Oficina de Textos, 2011.

MACHADO, T. G. Ambiente escolar infantil. 2008. 221 f. Dissertação (Mestrado em Arquitetura e Urbanismo) - Faculdade de Arquitetura e Urbanismo, Universidade de São Paulo, São Paulo, 2008.

ORNSTEIN, S.; ROMÉRO, M. Avaliação PósOcupação do ambiente construído. São Paulo: Nobel: Edusp, 1992.

PEGLOW, J. et al. Avaliação do conforto térmico de escola municipal de educação infantil em Pelotas/RS: ZB2. In: ENCONTRO NACIONAL DE TECNOLOGIA DO AMBIENTE CONSTRUÍDO, 16., 21-23 set. 2016, São Paulo. Anais... Porto Alegre: Antac, 2016.

RHEINGANTZ, P. A. et al. Observando a qualidade do lugar: procedimentos para a avaliação pós-ocupação. Rio de Janeiro: Universidade Federal do Rio de Janeiro, 2009.
Disponível em: <https://goo.gl/GQyEb1>. Acesso em: 10 jun. 2013.

SOUZA, F. S. Premissas projetuais para ambientes da educação infantil: recomendações com base na observação de três UMEls de Belo Horizonte, MG. 2009. 356 f. Tese (Doutorado em Arquitetura e Urbanismo) - Faculdade de Arquitetura e Urbanismo, Universidade Federal do Rio de Janeiro, Rio de Janeiro, 2009.

PEGLOW, J.; RITTER, V.; RONCA, A.; PEREIRA, R.; CUNHA, E.; RHEINGANTZ, P. A. Avaliação do conforto térmico de escola municipal de educação infantil em Pelotas/RS - ZB2. XVI ENTAC ENCONTRO NACIONAL DE TECNOLOGIA DO AMBIENTE CONSTRUÍDO. São Paulo: 2016.

ZABALZA, Miguel A. Qualidade em Educação Infantil. Porto Alegre: Artmed, 1998. 288 p.

ZEISEL, J. Inquiry by design. Monterey: Brooks/Cole Publishing Company, 1981.
Nébora Lazzarotto Modler nebora.modler@uffs.edu.br Angélica Saccol Berleze angelicaberleze@unochapeco. edu.br

Edison Kiyoshi Tsutsumi edison.tsutsumi@uffs.edu.br

Vinicius Cesar Cadena Linczuk vinicius.linczuk@uffs.edu.br

Giselle Arteiro Nielsen Azevedo gisellearteiro5@gmail.com 